\title{
Rodenticide poisoning in a Toxicological Assistance Center
}

\author{
Intoxicação por raticida em um Centro de Assistência Toxicológica
}

Beatriz Ferreira Martins ${ }^{1}$, Anai Adario Hungaro ${ }^{2}$, Jessica Adrielle Teixeira Santos ${ }^{3}$, William Campo Meschial ${ }^{1}$, Laiane Mucio Correia ${ }^{4}$, Magda Lúcia Félix de Oliveira ${ }^{1}$

Objective: to characterize rodenticide poisoning sold illegally under the name chumbinho. Methods: this is a descriptive and cross-sectional study by retrospective analysis of epidemiological forms of Toxicological Occurrence of a Toxicological Assistance Center, from 2006 to 2013. Results: 115 forms were analyzed, with an annual average of $14.4 \pm 4.8$ cases and $35.6 \%$ of the records in the fourth biennial. Most poisonings occurred in males (57.3\%), aged between 15 and 49 years (78.3\%) and suicide attempted (90.4\%). It was found clinical severity of cases because $92.1 \%$ intoxicated required hospitalization and occurred four deaths (3.5\%). Conclusion: the cases of poisoning by chumbinho increased gradually over the studied years, in males, in an economically active age, and by intentional poisoning. There is a need for greater sanitary inspection in the region, aiming to reduce supply and improvement of guidance to consumers.

Descriptors: Poisoning; Rodenticides; Health Surveillance; Poison Control Centers; Community Health Nursing.

Objetivo: caracterizar as intoxicações por raticida comercializado clandestinamente sob a denominação de chumbinho. Métodos: estudo descritivo e transversal, por análise retrospectiva de fichas epidemiológicas de Ocorrência Toxicológica de um Centro de Assistência Toxicológica, dos anos de 2006 a 2013. Resultados: foram analisadas 115 fichas, com média anual de 14,4 $\pm 4,8$ casos e 35,6\% dos registros no quarto biênio. A maioria das intoxicações ocorreu no sexo masculino (57,3\%), na faixa etária entre 15 e 49 anos (78,3\%) e pela circunstância tentativa de suicídio $(90,4 \%)$. Constatou-se gravidade clínica dos casos, pois 92,1\% intoxicados necessitaram de internação hospitalar e aconteceram quatro óbitos (3,5\%). Conclusão: os casos de intoxicação por chumbinho aumentaram gradualmente nos anos estudados, em indivíduos do sexo masculino, em idade economicamente ativa e por intoxicação intencional. Há necessidade de maior fiscalização sanitária na região, visando diminuição da oferta e aprimoramento das orientações aos consumidores.

Descritores: Envenenamento; Rodenticidas; Vigilância Sanitária; Centros de Controle de Intoxicações; Enfermagem em Saúde Comunitária.

\footnotetext{
${ }^{1}$ Universidade Estadual de Maringá. Maringá, PR, Brazil.

${ }^{2}$ Hospital Universitário Regional de Maringá. Maringá, PR, Brazil.

${ }^{3}$ Universidade de São Paulo. Ribeirão Preto, SP, Brazil.

${ }^{4}$ Hospital Paraná. Maringá, PR, Brazil.

Corresponding author: Beatriz Ferreira Martins

Rua Néo Alves Martins, 3341 apto 1202, CEP: 87013-060. Maringá, PR, Brazil. E-mail: biaferreira.martins@gmail.com
} 


\section{Introduction}

Illegal products have a high potential for serious toxicological events and are considered an emerging public health problem ${ }^{(1)}$. A group of illegal products of sanitary importance in our country, called chumbinho, is irregularly used as household cleaning and rodenticide, due to the belief of its high effectiveness, powerful lethality and fast mode of action in the fight against rodents. It also receives the name of "terrible chumbinho", "Japanese chumbinho", “Japan”, "powerful Japan", "three little steps", "strychnine", "mouse cachacinha" and "end of the rat"(2).

Since the middle 1990s, poisoning by chumbinho is considered an important cause of morbidity and mortality, suggesting health professionals began to observe systematically, and understand the clinical frame of poisoning by this product. In Brazil is gaining popularity as a suicide agent, homicide, and serious chemical accidents, due to easy access and low cost, exposing the population serious poisoning and often fatal, and increasing mortality rate among all products notified by Information Centers and Toxicological Assistance ${ }^{(1-3)}$.

Although poisonings are reportable, integrating the Damage Notification Information System, and most cases are attended in health services, it is estimated that the official records represent only $20 \%$ of cases occurring annually. Consequently, the records of the information and toxicological assistance centers are considered epidemiological sentinels of intoxication, captivators of social and health problems, susceptible to perform the Health Surveillance and Public Safety ${ }^{(4-5)}$.

Nurses, working in the Surveillance Health in toxicology centers and basic health services, as members of the multidisciplinary team of health care for the implementation of nursing care, play an importantrole in health education and implementation of poisoning prevention measures. Considering that mortality by toxicological events is related to late diagnosis and inadequate clinical management, and is essential, also, the training of health professionals for toxicological emergencies attendance ${ }^{(5)}$.

Information about the frequency and distribution of poisoning by chumbinho cases will subsidize the implementation of preventive and legal measures for its control. In this context, the question that guides the present study, contributing to the effort to confront this public health problem, was Which is the profile of poisoning by chumbinho reported in a service considered sentinel for toxic-vigilance? and the purpose of this article constituted to characterize rodenticide poisoning sold illegally under the name chumbinho.

\section{Methods}

This is a descriptive and cross-sectional study, with retrospective analysis of epidemiological forms of Toxicological Occurrence, filed in a Poisoning Control Center in the Northwest of Paraná, which conducts advisory and consulting for toxicological urgency/ emergencies, with qualified information to health professionals and the public in general to meet the toxicological accidents and represents an important source for assessing the reality of toxic accidents in the Northwest of Paraná, territory of the majority of reported $\operatorname{cases}^{(6-7)}$.

Secondary data subjects were studied with proven diagnosis of poisoning by chumbinho, registered in the Poisoning Control Center from January 2006 to December 2013, being excluded cases that had not necessary information for such confirmation. For confirmation of the case, the service uses clinical and epidemiological criteria - the existence of signs and/ or symptoms and exposure compatible history; or clinical and laboratory - the existence of signs and/or symptoms and results of compatible examinations; or proven contact report, even in the absence of clinical 
manifestations, considered as exposure ${ }^{(8)}$.

During the study period, 227 intoxication cases were reported with agents considered illegal, including sodium hypochlorite and manufactured and homemade detergents; pesticides and rodenticides smuggled or clandestinely manufactured, thus, being included in the study 115 cases of poisoning with the toxic agent chumbinho.

The data were accessed from epidemiological forms of Toxicological Occurrence, filed in a paper in the Poisoning Control Center. This form is filled intoxicated at the moment of the service of the intoxicated. It is a recording instrument used for all cases of poisoning and aggregates data about the characterization of the patient and toxicological accident and aims to facilitate clinical follow-up of cases, the implementation of preventive measures and epidemiological surveillance of events ${ }^{(8)}$.

The data collection was performed by documental analysis, and demographic variables of the case were analyzed - gender and age; the toxicological occurrence - intoxication circumstance and year of notification, ranked in biennial; the severity of the case - attendance in the residence/ domicile in primary health care, clinical observation and admission to Emergency Room, hospitalization ward or intensive care unit; and the clinical outcome of the case - cure, death/fatal exposure.

It is analyzed from a relatively small population, considered a research universe, which is defined as the set of individuals who share at least one common characteristic, basic units of people, objects or things, and which wishes to obtain information ${ }^{(9)}$. Thus, the phenomenon requirements suggest ways to better assessment of the data, thus, in this study were concentrated records from biennial years.

The variables under study were conceptualized and defined as Fill Manual Notification Form and Service of Toxicological Assistance Centers and for all variables was considered the item other for data: unk- nown, undetermined or ignored, however, after analysis records did not find data for this item ${ }^{(8)}$. The degree of severity of poisoning was established by the level of attention in the health institution and the symptoms presented by the intoxicated, understanding the greater complexity of care as more severe occurrence: Clinical observation at urgency/emergency room; hospitalization in urgency/emergency room; hospitalization in wards; and Hospitalization in intensive care unit $^{(10)}$.

The study variables were transcribed to a spreadsheet using Microsoft Excel ${ }^{\circledR} 2007$ software. For processing and analysis of data, a database on Epiinfo 3.5.1 software was constituted, and the results analyzed descriptively - absolute and relative frequencies.

The study complied with the formal requirements contained in the national and international regulatory standards for research involving human beings.

\section{Results}

In the six studied years, it was found 115 records of poisoning with the toxic agent chumbinho, representing $50.6 \%$ of total illegal product notifications. Before stratification by the notification year, it was found that the annual average of cases of poisoning by chumbinho was of $14.4 \pm 4.8$ cases, with a maximum annual rate of 41 cases in the fourth biennial (2012 and 2013) and minimum of 16 cases in the first biennial (2006 and 2007) (Table 1).

About demographic variables, 66 (57.3\%) events occurred in males, however, in the third biennial, the female occurrences totaled 21 (42.8\%) versus $16(24.3 \%)$ of male cases. There was also a heterogeneous distribution of age: in people aged 15 to 49 years, there was the highest numbers of cases $90(78.3 \%)$ but were registered 12 cases $(10.5 \%)$ of intoxication in children (Table 1). 
Table 1 - Distribution of poisoning by chumbinho, according to the notification year and characterization variables of the intoxicated and toxicology occurrence

\begin{tabular}{|c|c|c|c|c|c|}
\hline Year & 2006-2007 & 2008-2009 & 2010-2011 & 2012-2013 & Total \\
\hline Variable & n (\%) & n (\%) & n (\%) & n (\%) & n (\%) \\
\hline \multicolumn{6}{|l|}{ Gender } \\
\hline Male & $9(13.6)$ & 17 (25.8) & $16(24.3)$ & $24(36.3)$ & $66(57.3)$ \\
\hline Female & 7 (14.3) & $4(8.2)$ & $21(42.8)$ & $17(34.7)$ & $49(42.7)$ \\
\hline \multicolumn{6}{|l|}{ Age group (years) } \\
\hline$<15$ & $3(25.0)$ & - & $6(50.0)$ & $3(25.0)$ & $12(10.5)$ \\
\hline $15-29$ & $6(12,5)$ & $10(20.8)$ & $15(31.3)$ & $17(35.4)$ & $48(41.7)$ \\
\hline $30-49$ & $6(14.2)$ & $9(21.3)$ & $8(19.3)$ & $19(45.2)$ & $42(36.5)$ \\
\hline$>50$ & $1(7.7)$ & $2(15.4)$ & $8(61.5)$ & $2(15.4)$ & $13(11.3)$ \\
\hline \multicolumn{6}{|l|}{ Circumstance } \\
\hline Suicide attempt & $13(12.5)$ & $20(19.2)$ & $33(31.8)$ & $38(36.5)$ & $104(90.4)$ \\
\hline Individual accident & $3(27.3)$ & $1(9.0)$ & $4(36.4)$ & $3(27.3)$ & $11(9.6)$ \\
\hline Total & $16(13.9)$ & $21(18.3)$ & $37(32.2)$ & $41(35.6)$ & $115(100.0)$ \\
\hline
\end{tabular}

Table 2 - Distribution of poisoning by chumbinho according to the year of notification and variables of care characterization

\begin{tabular}{|c|c|c|c|c|c|}
\hline $2^{2}$ Year & $2006-2007$ & 2008-2009 & 2010-2011 & 2012-2013 & Total \\
\hline Variables & n (\%) & n (\%) & n (\%) & n (\%) & n (\%) \\
\hline \multicolumn{6}{|l|}{ Attention level } \\
\hline Primary Health Unit & $2(66.7)$ & $1(33.3)$ & - & - & $3(2.6)$ \\
\hline Observation in the emergency room & $2(33.3)$ & - & $4(66.7)$ & - & $6(5.2)$ \\
\hline Hospitalization in the emergency room & $6(13.0)$ & $7(15.2)$ & $20(43.5)$ & $13(28.2)$ & $46(40.0)$ \\
\hline Hospitalization in ward & $5(10.2)$ & $10(20.4)$ & $10(20.4)$ & $24(48.9)$ & $49(42.6)$ \\
\hline Hospitalization in intensive care units & $1(9.0)$ & $3(27.3)$ & $3(27.3)$ & $4(36.4)$ & $11(9.4)$ \\
\hline \multicolumn{6}{|l|}{ Outcome } \\
\hline Discharge & $16(15.2)$ & $16(15.2)$ & $34(32.4)$ & $39(37.2)$ & 105 (91.3) \\
\hline Transfer & - & $1(25.0)$ & $1(25.0)$ & $2(50.0)$ & $4(3.5)$ \\
\hline Evasion & - & $1(50.0)$ & $1(50.0)$ & - & $2(1.7)$ \\
\hline Death & - & $3(75.0)$ & $1(25.0)$ & - & $4(3.5)$ \\
\hline Total & $16(13.8)$ & $21(18.6)$ & $37(32.1)$ & $41(35.5)$ & $115(100.0)$ \\
\hline
\end{tabular}


Only two circumstances of poisoning, among the 15 listed in the Fill Manual Notification Form and Poisoning Control Attendance Centers ${ }^{(9)}$, were found: a suicide attempt or suicide in $104(90.4 \%)$ cases and individual accident in 11 (9.6\%). It was observed a significant temporal trend of increasing cases of suicide attempt in the fourth biennial, representing $35.6 \%$ of total cases by this circumstance during the study period (Table 1).

Concerning the severity estimate of cases, according to the level of health care and the complexity of care, in 106 (92.1\%) cases was nominated for hospitalization, which ranged from one to 24 days, averaging $3.8 \pm 4.4$ days. Eleven hospitalizations (9.63) occurred in intensive care units, 49 (42.6\%) in wards and $46(40.0 \%)$ in care units to urgency/ emergency room. The outcome of cases, most received improved hospital discharged, but six avoided or were transferred to another hospital service. Four patients drew attention, intoxicated by the circumstance suicide attempt that evolved to death (Table 2).

\section{Discussion}

Despite the study limitations, due to present data localized in only one area, the selected theme has relevance to Public Health and its results show that the chumbinho, due to its high toxicant power, is used as a lethal weapon for suicide and is involved in serious domestic accidents. The research is relevant because, with increasing trend of cases, managers of the Health sector need reliable information to guide strategies and actions of epidemiological and health surveillance, and limitations of information systems, make relevant data from the Toxicological Information Control Centers, which are considered sentinels of the event and captivators of its social problems.

Analyzing temporal trends of occurrences, in the fourth biennial (2012-2013) most poisonings by chumbinho were reported, corroborating epidemiological trend study data that showed an increase of $60.0 \%$ of case reporting for this agent in Brazil in the period of 2009 and 2011 and concluded that there was "epidemic outbreak" of toxicological event ${ }^{(4)}$.

The largest number of cases involving adults relates to the number of suicide attempts/suicide with the use of the product, considered one of the means for expanding these intentional acts ${ }^{(2-11)}$. The suicide attempt by chumbinho is considered an important cause of morbidity and mortality in Brazil and indicated by the World Health Organization as an increasing public health problem ${ }^{(12-13)}$.

The number of cases of suicide attempts may be related to the belief that the illegal product has a higher potential to lethal effect ${ }^{(4-6)}$. Studies show that men perform suicide attempts less often, but with more effective methods and have success suicide in greater numbers, while women have lower suicide success, for using chemical methods with less toxicity ${ }^{(10,14-15)}$.

Concerning individual accidents, which usually occur at home, by inadequate storage and use, mostly occurs in children up to eleven years old, with a positive clinical outcome ${ }^{(10)}$. A study performed to analyze the poisoning by chumbinho in Recife - Pernambuco, from 2007 to 2010 , obtained similar results $-18.3 \%$ of cases in children up to fourteen years of age, representing $76.6 \%$ of unintended reasons for intoxication ${ }^{(16)}$.

The severity of cases and the number of hospitalization in health care levels of medium and high complexity, which were rising in the studied biennial, indicate the agent's toxicity, the exposure to the product in larger doses, by the intent of the act, and the inadequate time access to health services for primary care and specific treatment to intoxication ${ }^{(5-17)}$. One of the findings of the study conducted in Recife was that $33.7 \%$ of patients were hospitalized and occupation of scarce vacancies in intensive care units ${ }^{(16)}$.

In the case of the outcome, the death rate is similar to developing countries and corroborates the need to elaborate preventive strategies aimed at reducing these events. Also, it can be related to late diagnosis, especially in cases of suicide attempted, 
where the patient performs the solitary act and does not receive early treatment, and inadequate conduct ${ }^{(10)}$. The initial approach of health team should be prompt and appropriate because the quickness diagnosis and early treatment are crucial in the clinical evolution and outcome of $\operatorname{cases}^{(3,5)}$.

The lack of information about these powerful toxic agents, for early detection of these health problems, guide measures for the restriction and indiscriminate access to pesticides, aware of the importance of using personal protective equipment, encourage the production and consumption of organic products and institute toxicological surveillance, are attitudes that need to be incorporated by extreme relevance to human health ${ }^{(10,13,18)}$.

The findings pointed potentiality for Nursing role because they need to be qualified for the casuistry, mainly in the care and treatment in urgency/ emergency situations with intoxicated people. Also, the team is responsible for developing promotion and prevention health actions, as a priority for the organization of an information system, which allows knowing the profile of health-disease, resulting from the exposure to chumbinho to promote the surveillance of populations.

\section{Conclusion}

The main findings of this study were the gradual increase in poisoning cases in the eight studied years and a higher incidence of males and suicide attempts in young adults, but the occurrence of accidental poisoning in children pointed out the presence of the product at home. A high number of hospital admissions and use of vacancies in intensive care units for all the cases was found, indicating the high potential severity of poisoning, because despite being a small value is highly representative for the event and indicates the need for preventive strategies, aimed at reducing cases.

It is important to discuss this casuistry in academic and professional circles, including Nursing sectors, to spread knowledge about the use of such product and the risks of intentional or accidental exposure, and alert managers and health professionals to the need for greater sanitary inspection and seizure of the product in the region, and to plead for the proactive surveillance of chemicals, with legislation and investment in comprehensive public policies.

\section{Collaborations}

Martins BF, Hungaro AA, Santos JAT, Meschial WC, Correia LM and Oliveira MLF participated in the conception and elaboration of the project, collecting and analyzing data, writing and critical analysis of the article and final approval of the version to be published.

\section{References}

1. Waseem M, Perry C, Bomann S, Pai M, Gernsheimer J. Cholinergic crisis after rodenticide poisoning. West J Emerg Med. 2010; 11(5):524-7.

2. Oliveira CS, Ferreira AP. Perfil epidemiológico das ações de vigilância em saúde das populações expostas aos agrotóxicos. Rev Saúde Meio Ambiente Sustentabil. [periódico na Internet]. 2012 [citado 2015 jul 15]; 7(1):18-33. Disponível em http://www.revistas.sp.senac.br/index.php/ ITF/article/viewFile/209/226

3. Cruz CC, Carvalho FN, Costa VIB, Sarcinelli PN, Silva JJO, Martins TS, et al. Perfil epidemiológico de intoxicados por aldicarbe registrados no Instituto Médico Legal nenhum Estado do Rio de Janeiro Durante o Período de 1998 a 2005. Cad Saúde Coletiva. 2013; 21(1):63-7.

4. Papini S, Nakagawa LE. Current status of rodenticide intoxication in Brazil: a preliminary survey from 2009 to 2011. Braz Arch Biol Technol. 2014; 57(5):685-8.

5. Silva ACS, Vilela FP, Brandão GMON. Intoxicação exógena por "chumbinho" como forma de autoextermínio no Estado de Goiás, 2003 - 2007. Rev Eletr Enf [periódico na Internet]. 2010 [citado 2015 jul 15]; 12(4):686-91. Disponível em: www. fen.ufg.br/fen_revista/v12/n4/v12n4a13.htm 
6. Santos JT, Seleghim MR, Marangoni SR, Gonçalves AM, Ballani TSL, Oliveira MLFO. Gravidade de intoxicações por saneantes clandestinos. Texto Contexto Enferm. 2011; 20(spe):247-54.

7. Tavares EO, Oliveira MLF. Padrões mínimos de atendimento inicial à urgência toxicológica para abordagem à criança intoxicada. Rev Rene. 2012; 13(1):147-57.

8. Santana RAL, Bochner R, Guimarães MCS. Sistema nacional de informações tóxico-farmacológicas: o desafio da padronização dos dados. Ciênc Saúde Coletiva. 2011; 16(Supl 1):1191-200.

9. Marconi MA, Lakatos EM. Técnicas de pesquisa: planejamento e execução de pesquisas, amostragens e técnicas de pesquisas, elaboração análise e interpretação de dados. São Paulo: Atlas; 1996.

10. Marangoni SR, Seleghim MR, Teixeira JC, Buriola AA, Ballani TSL, Oliveira MLF. Intoxications by pesticides recorded at a poisoning. Rev Enferm UFPE On line [Internet]. 2011 [cited 2015 jul 15]; 5(8):1884-90. Available from: http://www. revista.ufpe.br/revistaenfermagem/index.php/ revista/article/view/1897

11. Sabino BD, Torraca TG, Moura CM, Rozenbaum HF, Faria MVC. Development of a simple and low-cost enzymatic methodology for quantitative analysis of carbamates in meat samples of forensic interest. J Forensic Sci. 2010; 55(3):808-12.

12. Santos SA, Legay LF, Lovisi GM, Santos JCF, Lima LA. Suicídios e tentativas de suicídios por intoxicação exógena no Rio de Janeiro: análise dos dados dos sistemas oficiais de informação em saúde, 20062008. Rev Bras Epidemiol. 2013; 16(2):376-87.
13. Bucaretchi F, Prado CC, Branco MM, Soubhia P, Metta GM, Mello SM, et al. Poisoning by illegal rodenticides containing acetylcholinesterase inhibitors (chumbinho): a prospective case series. Clin Toxicol. 2012; 50(1):44-51.

14. Dantas JSS, Uchôa SL, Cavalcante TMC, Pennafort VPS, Caetano JA. Perfil do paciente com intoxicação exógena por "chumbinho" na abordagem inicial em serviço de emergência. Rev Eletr Enf [periódico na Internet]. 2013 [citado 2015 jul 10]; 15(1):54-60. Disponível em: https://www.fen.ufg. br/fen_revista/v15/n1/v15n1.htm

15. Eddleston M, Bateman DN. Major reductions in global suicide numbers can be made rapidly through pesticide regulation without the need for psychosocial interventions. Soc Sci Med. 2011; 72(1):1-2.

16. Medeiros MNC,Medeiros MC,SilvaMBA.Intoxicação aguda por agrotóxicos anticolinesterásicos na cidade do Recife, Pernambuco, 2007-2010. Epidemiol Serv Saúde. 2014; 23(3):509-18.

17. Oliveira MLF, Buriola AA. Gravidade das intoxicações por inseticidas inibidores das colinesterases no noroeste do estado do Paraná, Brasil. Rev Gaúcha Enferm. 2009; 30(4):648-55.

18. Oliveira WN, Silva EX, Sousa JR. Envenenamento por carbamato: relato de caso. Derecho Cambio Soc [periódico na Internet]. 2014 [citado 2015 jul 10]. Disponível em: http:// www.derechoycambiosocial.com/revista036/ ENVENENAMENTO_POR_CARBAMATO_RELATO_ DE_CASO.pdf 